\title{
Review of Literature on The Impact of Foreign Workers on Wages Keywords:Foreign Workers; Wages
}

\author{
Sri Wahyuni ${ }^{1}$, Nasri Bachtiar ${ }^{2}$, Elfindri ${ }^{2}$, and Endrizal Ridwan ${ }^{2}$ \\ \{wahyuni1313@gmail.com\} \\ ${ }^{1}$ Department of Economics, Universitas Almuslim, Bireuen, Indonesia \\ (Economic student of doctoral program in Andalas University) \\ ${ }^{2}$ Department of Economics, Universitas Andalas, Padang, Indonesia
}

\begin{abstract}
This paper reviews the current theoretical and foreign workers research with a particular emphasis on the impact of foreign workers on wages level. In general, the model that is used to measure the impact of foreign workers on wages level is Constant Elasticity of Substitutes model (CES), assimilation economic model, cohort effect model, spatial correlation model, Total Factors Productivity (TFT), Skill-Biased Productivity (SBP), standard cross-section and other estimation models. The research results found are different, thus emerging the positive and negative effect. The positive impact is the optimism of the impact of foreign workers' presence on local workers with high skills and experience. The group of high skill and experience shows that the relations between local and foreign workers are complementary and causes the transfer of technology and knowledge level, as well as the wages of local workers, tend to increase. Meanwhile, the negative impact is the pessimism of the impact of foreign workers' presence on local workers with low skills. The group of low skill and experience are substitutionary and causes increased unemployment, as well as the wages of local workers, tend decline.
\end{abstract}

Keywords: Foreign Workers; Wages

\section{INTRODUCTION}

The phenomenon of foreign workers in the process of globalization and the development of major world economy in an effort to improve competitiveness so that the establishment of cooperation labor mobility. Cooperation between countries is one form of self-protection from these countries (Smith, 1998). Foreign workers will come to countries that economic growth high [1] mostly Chinese and Indian immigrants emigrating to high GDP countries. High economic growth due to the increase of productivity, and capital investment and many emerging new industries that eventually led to increased demand for foreign workers [2]. Meanwhile, Duwicquet et.al, stated that migration policy countries China and India have put local workers prefer to work in the villages rather than in the industrial sector. 
It begins with one of Cobb Douglas's production function which states that the workers are homogeneous cause the current research to emerge that break the assumptions. The initial current research was developed by Borjas, Card, Dustmann, Peri, Ottaviano, and others. Some research analyzes that workers are heterogeneous and classifying in some groups such as gender, foreign or local, education level, skills level, experience level and others. This classification will have an impact of wages level, in accordance with Hicks, 1932 on the wages theory that states that the differences in net economic profit, especially in the wage rate differences between countries, lead to the emergence of immigration or foreign workers [3]. This research emphasized on the review some research results of the impact of foreign workers on the level of the wages of local workers. This review can be divided into two groups of optimists and the pessimists.

\section{THE BASIC LABOR MOBILITY FRAME}

Trade was first introduced by Adam Smith in 1776 with the concept of absolute advantage and division of labor. Ricardo (1817) with the theory of comparative advantage [4]. The Heckscher-Ohlin (HO) theory attempts to empirically to link the endowment structure with production. The HO model assumption is that there are only two countries, using the same technology, constant scale of return, two commodities, perfect competence, perfect factor production mobility, no barries cost. Paul Samuelson developed the HO model known as HOS theory where equates the factor prices of production factors [5]. Besides, Vanek assumed the technology constant return to scale and costless trade with the assumption $\mathrm{m}=\mathrm{n}$, there is a linear relationship between output and endowment [6]. Until now, HOS theory continues to be developed by the researchers.

The HO model put trade among countries that relative endowment factors. The country will produce labor-intensive goods when having relative labor endowment that is capital and human. In addition, a country will produce labor when only have the relative labor. In the long term, free trade will have an impact on countries that have labor endowment will slump its economy where the wages of labor unskilled will fall on the countries relative capital yield. In contrast, economic developments occur in countries with the capital endowment [7]. Cunat and Melitz, [8] using the Ricardian model added that comparative advantages predict the volatility in the production of goods will be higher in a country with a flexible labor market flexible compared to a country with a rigid labor market.

Borjas is one of the researchers who stated that workers are heterogeneous and this was followed by some other researchers. Although, the researchers have the same assumption about workers is heterogeneous, the use of model, sampling and research results on the impact of foreign workers to the level of wages have always been a long debate to date. Borjas criticized several models for estimating the level of wages, including Roy Model and Linear Utility "Generalized" Positive Selection.

Roy Model distinguishes three distinct skills between local and foreign workers is a positive selection, where the average income of foreign workers in above the local workers. Negative selection, where the average income of foreign workers is below local workers. While the third is the final selection of foreign workers get average income under the origin country and get good treatment in the host country. This these statements show that although the gap between state revenues and cost affect the selection of foreign workers, however, the selection process expertise that determines the presence of foreign workers. Borgas assumes 
that Roy's model does not see when there is a large wave of immigration/foreign workers that may affect the wage structure of both countries. In addition, in research of and Docquier and Marfouk [9] considers that the use of Roy's model is still limited because they do not pay attention to the education owned by each country [3].

Grogger and Hanson [10] tried to examine with other alternative models that are "generalized" positive selection. This model is very easy to see the difference in wages between two skills (i.e. high skills and expertise low) through linear utility framework. This distinction will eliminate the fixed costs of foreign workers because expertise is independent. Positive selection will see the wage gap between the host country and the origin country is greater in the high-skilled workers' group than in the low-skilled workers' groups. However, in the linear utility framework will show distracting, dynamic implications of attractiveness. It is anticipated that there will be massive displacement of high-tech expertise groups due to the absence of migration costs. [3]

In addition, there are also economic assimilation models, aging and cohort effects that affect the level of wages. The Model of assimilation explained that no data cross section described by Chiswick [11] to determine the level of wages such as length study and length of experience that is constantly changing over time. In addition, aging and cohort effects also determine in making a methodology for analyzing the level of wages [3].

Based on the above framework, Borjas devised a model to determine the impact of foreign workers on wages level. The production function with heterogeneous workers i.e. $Q=f\left(K, L_{1}, \ldots, L_{z}\right)$, where $\mathrm{Q}$ is output, $\mathrm{K}$ is modal and $p$ is the output prices, and $\mathrm{L}$ is heterogenous labor $\left(L_{1}, \ldots, L_{z}\right)$. Heterogeneous workers will affect wages level in each skill group $m_{i}=\frac{d L_{i}}{L_{i}}$, where $m_{i}$ represents a shift in the supply curve of host country's labor market. Development of the model framework of Constant Elasticity of substitution (CES) is as follows:

$$
\begin{aligned}
& Q=\left[\alpha K^{\delta}+(1-\alpha) L^{\delta}\right]^{1 / \delta} \\
& L=\left[\theta_{1} L_{1}^{\beta}+\theta_{2} L_{2}^{\beta}\right]^{1 / \beta}
\end{aligned}
$$

Equation (1) is a function of the aggregate production and equation (2) is a function of the homogeneous workers in various occupations in the standardization of efficiency units. The Elasticity of substitution between capital and labor is $\sigma_{K L}=1 /(1-\beta)$ while the elasticity of substitution between the skill groups is $\sigma_{12}=1 /(1-\beta)$ with $\beta \leq 1$ and $\theta_{1}+\theta_{2}=1$, changes the number of standardization of efficiency units in heterogeneous workers is:

$$
d \log L=\frac{s_{1} m_{1}+s_{2} m_{2}}{s_{L}}=\bar{m}
$$

In equation (3) there is no longer required values $\sigma_{12}$ and $\sigma_{K L}$ because there are already contained in the equation. Furthermore, the wage formula at input $i$ is equal to the marginal utility is:

$$
w_{i}=\left[(1-\alpha) Q^{1-\delta} L^{\delta-1}\right] \theta_{i} L^{1-\beta} L_{i}^{\beta-1}
$$

Equation (4) wages or marginal productivity is still in homogenous workers. To obtain the impact of the foreign workers on the relative wage rate dependent on the substitution elasticity, and then substituting equations (3) and (4) becomes:

$$
\begin{aligned}
& d \log w_{i}=d \log w+(1-\beta) d \log L+(\beta-1) d \log L_{i}, \\
& d \log w_{i}=d \log w+(1-\beta)\left(\bar{m}_{1}-m_{2}\right)
\end{aligned}
$$

Furthermore, the effect of distribution is:

$$
d \log w_{1}-d \log w_{2}=-\frac{1}{\sigma_{12}}\left(m_{1}-m_{2}\right)
$$


Foreign workers will have no effect on relative wages when both groups are perfect substitutes $\left(\sigma_{12}=\infty\right)$. Furthermore, foreign workers will affect relative wages when both groups are imperfect substitutes, where the magnitude of supply shock will decrease relative wages. Distributional effects also affect the average wages as well as in homogenous workers conditions so that $d \log \bar{w}=d \log w$. Based on Cobb-Douglas production function in the short term, there is greater $-3 \%$ wage effect in one group and less than $-3 \%$ wage effect to other groups in the case of an increase in the labor force due to the presence when adding the workforce as a result of the coming of the foreign workers by $10 \%$. To determine the structure of wages based on the region or area then Borjas using spatial correlation approach and can estimate the national labor market [3].

Some researchers criticize the results of the research that has been done by Borjas. Gochenour [12] assess the Borjas too focused on the impact of immigrants/foreign workers on the labor market. His research in the Immigration Economics book does not answer the influence of political economies such as the effect on the welfare of the host countries, fiscal health host country, and the policies of the host country. In general, Borjas's research does not analyze the results of the research using appropriate meta-analysis because he only explains the results based on the CES model to analyze the effects of immigration/foreign workers on the labor market and empirical findings only.

Peri [13] assess that research produces the spurious correlation with mobility model. This is caused in measuring the pressure of the Borjas immigrants/foreign workers using parameter estimation $\rho$ where there should be a positive bias in the partial correlation between the wages of local workers with immigrant/foreign workers shock but resulting in a negative bias. Using the CES model emerges the level of substitution between foreign and local workers because workers with similar educational and characteristics will differ in their treatment of the labor market. So, there are still many variants which have not been identified in the Borjas researches.The CES Model is not able to explain the effect of the average wages in the long term, even though it establishes a 10\% increase in foreign workers will affect $-3 \%$ wages. This is due to constant capital costs. It is important to be noted that technology and human capital continue to change so that it is impossible to remain and this applies to foreign and local workers.

Mandelman and Zlate [14] State that Borjas's research examined the national level through spatial correlation. His researches focus on spatial correlation to gain wage effects by combining job skill group work which resulted in wage elasticity at the national level. There are 3 things that should be noted are: 1) the skill group does not fix over time so that the impact of foreign workers on the wages of local workers may occur but local workers have shifted to higher level of expertise, 2) there are other factors that affecting the wages of local workers other than foreign workers (e.g. technology), and 3) a national level approach assumes that foreign workers are exogenous factor over time meanwhile Borjas makes foreign workers as endogenous factor as the result will be biased at the national level. The response to the wages of local workers is also very small and this is evidenced by no negative effects in Metropolitan Statistical Areas (MSA) or country level.

Borjas's research often uses the CES model that is flexible enough to estimate relative wage effects of foreign workers across educational groups where it is determined by a shift in the labor supply. But the CES model has 4 weaknesses. First, it does not look at the elasticity of substitution between foreign and local workers in the skill group because it only sees the relative labor supply shift across the skills group and on the short-term effects on the average wages depends on the elasticity of substitution on the skill level. Second, it does not estimate 
the substitution elasticity between capital and labor. Third, labor supply to average wages is zero. Fourth, the assumption of equality of substitution elasticity in all skill groups.

\section{The impact of foreign workers on wages level: optimistic and pessimistic}

The research results of the impact of foreign workers on wages level are beneficial or harmful to local workers. The different usage models, locations, sampling that produce a positive and negative impact.

Table 1. Results of the impact of foreign workers on wages level and economic growth researches

\begin{tabular}{|c|c|}
\hline Impact on wages level & Impact on economic growth \\
\hline $\begin{array}{l}\text { The presences of foreign workers bring } \\
\text { positive impact on the local workers } \\
\text { specifically high-educated such as } \\
\text { professional workers, technical } \\
\text { supervisors. In addition, wages will } \\
\text { remain high when foreign workers are } \\
\text { able to speak English and obtain the } \\
\text { permanent residency }\end{array}$ & $\begin{array}{l}\text { Increasing output (GDP), employment } \\
\text { opportunities and economic growth of host } \\
\text { countries }\end{array}$ \\
\hline $\begin{array}{l}\text { The presence of foreign workers, } \\
\text { especially low-skilled, and this caused by } \\
\text { the substitution relationship between } \\
\text { foreign and local workers }\end{array}$ & $\begin{array}{l}\text { Inequality wages where local workers feel } \\
\text { threatened with low payments and companies } \\
\text { recruit more foreign workers that will increase } \\
\text { unemployment and lower purchasing power } \\
\text { so that the country's GDP will descend }\end{array}$ \\
\hline $\begin{array}{l}\text { The presence of new foreign workers } \\
\text { affecting the incumbent foreign workers }\end{array}$ & $\begin{array}{l}\text { Inequality wages where incumbent foreign } \\
\text { workers feel threatened by the low pay and } \\
\text { more companies recruit new foreign workers } \\
\text { and reduce incumbent's remittances. }\end{array}$ \\
\hline
\end{tabular}

The presence of foreign workers brings positive impact on the local workers specificallyeducated in accordance with the research Islam, Islam, and Nguyen [15] examine the relationship between skilled foreign workers, innovation, and wages of local workers. This study used two analyzes: data at the individual level for estimation of foreign workers contribute to the capacity of innovation of local and state workers for patent rights to wage levels and unpatented workers. The findings are an increase of foreign workers will provide opportunities for local workers get patents in innovation so that the weekly wages of local workers will also increase as well as commercial patent right. Besides, that foreign workers also give the positive impact on higher wages on the state and all local workers both skilled and unskilled.

Peri and Foged [16] in the research of the foreign workers on local workers in Denmark using longitudinal data during the period of 1991-2008 ie data from the Danish Integrated Database for Labor Market Research (IDA). This research found that the entry of the lowskilled foreign workers had a positive positive impact on the low-skilled local in Denmark, especially in refugee areas, where low increased. 
Peri, Shih, and Sparber [17] compare the productivity of foreign workers and local workers based on the type of the work of science and technology, engineering, mathematics (STEM) seen from the ownership of $\mathrm{H}-1 \mathrm{~B}$ as inputs for innovation in the cities of the United States. To avoid the influence of the great recession, the analysis is divided into 1990-2000, 2000-2005. The method used there are 2 ie 1) O*Net database from ILO, and 2) identify the STEM occupations based on the skills workers possess before employment. Research findings STEM foreign workers are able to raise the wages of highly educated local workers and increase economic growth through productivity. In the long term, this research uses the Total Factors Productivity (TFT) and Skill-Biased Productivity (SBP), with the result of the increase of $1 \%$ of the market share of foreign workers with STEM will increase the wages of educated local workers by 7-8 \% and not in college group by 3-4 \% .

Pinto and Michaelis [18] using the Melitz model to analyze the effects of the labor market from the effects of the trade liberalization by combining trade unions with heterogeneous workers. Finding that trade liberalization has negative effects for workers while highly skilled workers will benefit from high wages. In addition, the amount of low skilled labor will lead to increased unemployment and the welfare of the country will be dangerous and this is present in the characteristics of the wage offer.

Brucker and Jahn [19] using IABS analysis for data processing of German workers been recorded from the year 1975-2004 in analyzing the foreign workers and wages in the reexamination of the effects of the labor market. Immigrants/foreign workers will affect the unemployment rate depending on education, work experience level and wage flexibility. High labor supply with high wage flexibility and low unemployment will make the company add workers to lower wages and become substitutes for education and lower experience in the labor market. However, for highly skilled workers it will in the long run benefit local skilled workers

Mukhopadhyay and Oxborrow [20] analyzing the work based on the green card with data sources fro (NIS). Classification of the work based on the census of 4 digits and 5 occupational categories namely professional and managerial, health, services, sales and administrative, and another obvious lesson, where the green card recipient is $\mathrm{R}=1$ and that is not $\mathrm{R}=0$. This research estimates the increase of foreign workers wage based on the acquisition permanent residency in the United States. The findings in this study of foreign workers wages will increase after obtaining a permanent residency because the increasing population keeps the employers must pay foreign workers wages in the wages of local workers. Increased green card enforcement will make high-skilled foreign workers mobility impaired because and employers have more power. The employer is judged to be able to suppress wages and compare them with local workers.

Schoellman [21] by developing a comparative advantage model in the labor market with heterogeneous workers and using CES to analyze employment outcomes in aggregate to examine the differences in work based on human capital owned by foreign and local workers in the United States. The source of the data from the two sources namely 1) data the census of the United States to see the origin country of birth and type of work based on the Standard Occupation Classification (SOC) system, and 2) data $\mathrm{O}^{*} \mathrm{Net}$ to see the behavior of the work. The comparative advantages that are owned by the workers make workers freely determine the work in accordance with their skills and expertise. Foreign workers prefer employment based on cognitive-intensive skills in the field of science and physical skills. While local workers work more intensively-communicative like managers and reparations. The result of the study shows that the increase of wages due to foreign workers is only $0.3 \%$ 
while the wage decrease is $2.8 \%$ and the decrease is mostly in the intensive work of cognitive skills.

Chiswick and Miller [11] examine the negative model of immigrant assimilation in the United States, with foreign workers data from English-speaking developing countries from the 1980, 1990, and 2000 censuses. Foreign workers who are the subject of research from Canada, United Kingdom, Ireland, Australia and New Zeland. The model of assimilation analyzes the group of workers based on the classification of English skills and proficiency. If skill transfer gets high price/wage for foreign workers then there will be positive assimilation. While the declining skills and the decrease in price/wages of foreign workers will result in negative assimilation. Using the standard cross-sectional approach and the cohort of the relative income model of foreign workers continues to diminish over time. However, this income/wage will remain high if able to speak English.

Asali [22] analyzes Israel's labor market of varying numbers of foreign and local workers using a quasi-experimental approach done to see the political instability and border area policy. The Levant Event-Type Counts DataSet is used for conflict data that is done every week. Estimates adopted Borjas for analyzing the quarterly rate. The research findings are a Palestinian worker complement with local workers Israel Arabs and this does not affect the Israel Jewish. Foreign workers (other than Palestine) do not affect the wages of local workers. In the event of a 10\% induced Palestinian pardon inducement in the industrial sector, it would increase Israel's Arab wage by $3.4 \%$ but not with Israeli Jewish wages. This means that Palestinian workers do not affect the wages of Israeli Jewish workers but increase the wages of Israeli Arab workers.

Negative influence also occurs on the substitution relationship between foreign and local workers for the highly educated. Peri [23] in the period 1970-2014 there was a shift in the labor supply curve relative to the presence of foreign workers affecting the wages of local workers in the United States. The model used is CES by identifying based on high school and non-high school educated groups which are a combination of imperfect substitution between high school and high school dropout. The entry of foreign-educated high school workers lowers the relative wages of non-high school workers. Wage gaps occur in non-high school or low-skilled workers for the period 1900-2000. This study concludes that foreign workers do not negatively affect the wages of local workers. In 2010, foreign workers have a positive influence on the rising wages of local workers who have high school education or not.

Dustmann, Schönberg, and Stuhler [24] focused their research on wage analysis by ignoring the employment response, as well as using the national skill-cell and mixture approach with immigrant and local assumptions having the same level of education and experience in three countries: United State, United Kingdom, and Germany. In addition, the basic explicit parameter estimation approach is explicit in the canonical model to predict the effect of immigrant wages. The results showed that foreign workers responded to heterogeneity. Estimation of the effect of relative wages of immigrants with the national skillcell approach is misleading and difficult to interpret for the total effect of foreign workers as a whole. Downgrades will lead to biased estimates in the national skill-cell approach and mixture approach as both depend on variations in immigration inflows of skill alerts. In the United States and some countries, however, the influence of wages is relatively negative with experience in national skill-cell approach and also negative with education using mixture approach, but the national skill-cell total approach immigration effect strongly strengthens the downgrade and does not need assessment of skill immigration.

Ruist [25] analyzed the wage gap between foreign and local workers using data from the US census 1960-2006, with a classification of 4 education groups and 8 experience groups. 
Estimates were made using Elasticity of Substitution in accordance with [26]. The research findings do not occur perfect substitution of foreign and local workers in the United States. and complementary relationships were not found in this study. So that the average wage of foreign workers will be low if the number of foreign workers is high. The individual wages of foreign workers will lower or average relative wages of local workers, in the case of a complementary relationship between foreign and local workers because local workers have been divided into workplaces. It is different with Ottaviano and Peri who find that foreign workers (based on European countries in Germany) have negatively affected the incumbent and positive foreign workers with local workers.

In general, the negative effect of foreign workers on the level of wages of local workers tend to be in the low skill groups, and this causes the pessimists to be exposed to the presence of foreigners Bettin, Lo, and Daniela [27] studied foreign workers in the Italian manufacturing sector in the 9th wave survey period 2001-2003. this study uses a production function approach also analyzes the factor of price changes on labor inputs for the level of output produced and uses the Morishima Elasticities of Substitution (MES) to assess the relations of foreign and local workers in production. Although the output elasticity of foreign workers is lower, the addition of foreign workers is able to increase production and bring about changes in output. If the price of skilled workers is increasing, so companies will tend to ask for foreign workers and substitutes for low-skilled local workers. So there is substitution between foreign workers and local skilled workers.

Borjas [28] the shock supply of foreign workers in Miami as a whole did not significantly affect wage structures, but more impacted on low-skilled and unprofessional local workers. While in Florida, high school drop-out rates and college dropped 10-30\% between the periods 1977-1979 and 1981-1986. Overall the Marielitos had a negative effect on wages throughout the placebo.

Dustmann, Frattini, and Rosso [29] The emigration cause low wages to low-skilled workers and only a modest increase in wages to medium- and high-skilled workers and this is in accordance with the research. Borjas, Grogger, and Hanson [30] using the demand function and estimate the wage rate through CES model. The study found that a decrease in black wage rates by $3 \%$ and reduced employment by $5 \%$ in the case of an increase in foreign workers by $10 \%$. This research is also in line with the results of research by other researchers: [2], [18], [31]-[34].

Negative impact not only on local workers' wages but also on immigrant wages. Manacorda and Manning [35] new immigration lower incumbent immigrant wages compared to local workers in the United Kingdom. Felbermayr, Geis, and Kohler [36] the presence of new immigration has negatively affected the wages of incumbent immigrants but has no effect on local workers. But Peri and Foged [16] found immigrants to have a positive impact on lowskilled local workers' wages in Denmark.

In addition to the empirical research the impact of foreign workers on wages of that done in continental Europe and the United States. Research the impact of foreign workers also conducted in ASEAN countries, especially Malaysia. [37] Professional foreign workers and technical supervisors have a positive relationship to foreign wage levels but have a negative relationship with capital goods and local wage rates. Therefore, the development of high-tech industries led to the need for cooperation between industries and universities in producing skilled labors. Ismail, Yussof, and Awad [38] foreign workers reduce the wages of local workers in Malaysian companies, in particular, the service sector, but this is different from professional wages. Yean and Siang [39] estimate wage and labor demand levels by deriving Cobb Douglas production function. The use of foreign workers has a very small negative 
impact on all workers both foreign and local and not in all work groups in Malaysian manufacturing sector in the 2000-2006 periods.

\section{Conclusions}

The emergence of optimistic and pessimistic groups of foreign workers against wage levels is due to different research results. The diversity of the results of this study is due to the use of models in measuring the level of wages. In general, the models often used to measure the impact of foreign workers on the wage rate are the Constant Elasticity of substitutes (CES) model, economic assimilation, cohort effect, spatial correlation, Total Factor Productivity (TFT) and Skill-Biased Productivity (SBP), standard cross-section and other estimation models. However, it is not only the model that determine the difference of research results, sampling and location also determine the different results. The difference in determining the model of measuring the impact of foreign workers on wage rates continues to be a matter of debate to date.

The optimism for the presence of foreign workers occurs when the relations of foreign and local workers complement, where there will be the transfer of technology and science and can increase the wages of local workers, and vice versa pessimism will occur. Complementary relationships often occur between high-skilled foreign and local workers and substitutions occur between low-skilled foreign and local workers. Although there are several studies that find that the presence of foreign workers does not only affect local workers but foreign workers are incumbent.

\section{Acknowledgements}

This research is supported by Ministry of Research, Technology, and Higher Education in providing assistance education costs of a doctoral program. We are grateful to the friend agonizing from the Economics Faculty of Almuslim University which has provided assistance in completing this research. Courtesy of the lecturers Faculty of Economics Andalas University who gave the instruction and input to the completeness of this research. Do not forget their counterparts in the draw of economic science at Andalas University.

Thank you infinitely to the WMA committee who has provided direction and input to this review literature research. Thanks to the editors and referees who helped shape an article. All mistakes and writings are the responsibility of the author.

\section{References}

[1] V. Duwicquet, E. M. Mouhoud, and J. Oudinet, "International migration by 2030 : impact of immigration policies scenarios on growth and employment," Foresight, vol. 16, no. 2, pp. 143164, 2014.

[2] Islam F; Khan S, "The long run impact of immigration on labor market in an advanced economy,” Int. J. Soc. Econ., vol. 42, no. 4, pp. 356-367, 2015.

[3] G. J. Borjas, Immigration Economics. Cambridge, Massachusets, London, England: Harvard Universty Perss, 2014.

[4] P. L. A. Batres, "Efficient labor reallocation and the liability of localness Unintended 
consequences of NAFTA and," Am. J. Bus., vol. 27, no. 1, pp. 79-90, 2012.

[5] D. Salvatore, International Economics, 11th Editi. the United States of America: the Permissions Department, John Wiley \& Sons, Inc, 2013.

[6] D. R. Gaston N; Nelson, "Bridgin trade and labour econometrics: The effects of international migration,” J. Econ. Surv., pp. 1-53, 2011.

[7] L. Calmfors, G. Dimdins, M. Gustafsson, H. Montgomery, and U. Stavlöt, "Why do people dislike low-wage trade competition with posted workers in the service sector?," J. Socio. Econ., vol. 47, pp. 82-93, 2013.

[8] A. Cunat and M. J. Melitz, "Volatility, labor market flexibility, and the pattern of comparative advantage," J. Eur. Econ. Assoc., vol. 10, no. 2, pp. 225-254, 2012.

[9] F. Docquier and A. Marfouk, "International migration by education attainment, 1990-2000," Int. Migr. Remit. brain drain, pp. 151-199, 2006.

[10] J. Grogger and G. H. Hanson, "Income maximization and the selection and sorting of international migrants," J. Dev. Econ., vol. 95, no. 1, pp. 42-57, 2011.

[11] B. R. Chiswick and P. W. Miller, "The 'negative' assimilation of immigrants: a special case," Ind. Labor Relations Rev., vol. 64, no. 3, pp. 502-525, 2011.

[12] Z. Gochenour, "George J. Borjas: Immigration economics," B. Rev. Public Choice, vol. 164, pp. 443-445, 2015.

[13] D. Card and G. Peri, "by George J . Borjas : A Review Essay †," J. Econ. Lit., vol. 54, no. 4, pp. 1333-1349, 2016.

[14] F. S. Mandelman and A. Zlate, "Economic aspects of international labour migration," B. Rev. Int. Financ., vol. 20, pp. 100-112, 2017.

[15] A. Islam, F. Islam, and C. Nguyen, "Skilled Immigration, Innovation, and the Wages of Native-Born Americans *," Ind. Relat. (Berkeley)., vol. 56, no. 3, pp. 459-488, 2017.

[16] G. Peri and M. Foged, "Immigrants 'Effect on Native Workers : New Analysis on Longitudinal Data," IZA Discuss. Pap., no. 8961, 2015.

[17] G. Peri, K. Shih, and C. Sparber, "STEM Workers, H-1B Visas, and Productivity in US Cities," J. Labour Econ., vol. 33, no. 3, pp. 225-255, 2015.

[18] M. De Pinto and J. Michaelis, "International Trade and Unemployment - the Worker-selection Effect," Econ. Lett., vol. 22, no. 2, pp. 226-252, 2014.

[19] H. Brucker and E. J. Jahn, "Migration and Wage-setting : Reassessing the Labor Market Effects of Migration * ," Scand. J. Econ., vol. 113, no. 2, pp. 286-317, 2011.

[20] S. Mukhopadhyay and D. Oxborrow, "The Value of an Employment-Based Green Card," Demography, vol. 49, pp. 219-237, 2012.

[21] T. Schoellman, "The Occupations and Human Capital of U . S . Immigrants," J. Hum. Cap., vol. 4, no. 1, pp. 1-34, 2010.

[22] M. Asali, "The effects of ( different types of ) immigrants on labor market outcomes of ( different groups of ) natives," Int. J. Manpow., vol. 38, no. 3, pp. 338-353, 2017.

[23] G. Peri, "The Impact of Immigration on Wages of Unskilled Workers," Cato J., vol. 37, no. 3, pp. 449-460, 2017.

[24] C. Dustmann, U. Schönberg, and J. Stuhler, "The Impact of Immigration: Why Do Studies Reach Such Different Results?,” J. Econ. Perspect., vol. 30, no. 4, pp. 31-56, 2016.

[25] J. Ruist, "Immigrant - native wage gaps in time series : Complementarities or composition effects ?," Econ. Lett., vol. 119, no. 2, pp. 154-156, 2013.

[26] G. I. P. Ottaviano and G. Peri, "Rethinking the effect of immigration on wages," J. Eur. Econ. Assoc., vol. 10, no. 1, pp. 152-197, 2012.

[27] G. Bettin, A. Lo, and T. Daniela, "A firm level perspective on migration : the role of extra-EU workers in Italian manufacturing," J Prod Anal, vol. 42, pp. 305-325, 2014.

[28] G. J. Borjas, "The wage impact of the marielitos : a reappraisal," ILR Rev., vol. 70, no. 5, pp. 1077-1110, 2017.

[29] C. Dustmann, T. Frattini, and A. Rosso, "The Effect of Emigration from Poland on," Scand. J. Econ., vol. 117, no. 2, pp. 522-564, 2015.

[30] G. J. Borjas, J. Grogger, and G. H. Hanson, "Immigration and the Economic Status of African- 
American Men," Economica, vol. 77, pp. 255-282, 2010.

[31] C. Bartolucci, "Understanding the Native-Immigrant Wage Gap Using Matched EmployerEmployee Data: Evidence from Germany," vol. 67, no. October, pp. 1166-1202, 2014.

[32] T. SrungBoonmee, "Immigration and US native workers ' wages : differential responses by education," Int. J. Manpow., vol. 34, no. 5, pp. 447-464, 2013.

[33] M. Howland and D. Nguyen, "The Impact of Immigration on Four Low-Wage Industries in the 1990s," Econ. Dev. Q., vol. 24, no. 3, pp. 99-109, 2010.

[34] F. Lehmer and J. Ludsteck, "The impact of immigration on the structure of wages: Theory and evidence from Britain," Rev. Income Wealth, vol. 61, no. 4, pp. 677-702, 2015.

[35] M. Manacorda and A. Manning, "The impact of immigration on the structure of wages: Theory and evidence from Britain," J. Eur. Econ. Assoc., vol. 10, no. 2, pp. 120-151, 2012.

[36] G. Felbermayr, W. Geis, and W. Kohler, "Restrictive immigration policy in Germany : pains and gains foregone?," Rev World Econ, vol. 146, pp. 1-21, 2010.

[37] N. Bachtiar, R. Fahmy, and R. Ismail, "The Demand for Foreign Workers in the Manufacturing Sector in Malaysia," J. Ekon. Malaysia, vol. 49, no. 2, pp. 135-147, 2015.

[38] R. Ismail, I. Yussof, and A. Awad, "The Impact of Foreign Workers on Wages : A Case Study of Malaysian Firms Rahmah ISMAIL * Ishak YUSSOF Atif AWAD," Int. J. Econ. Perspect., vol. 8, no. 3, pp. 64-75, 2014.

[39] T. S. Yean and L. C. Siang, "The impact of foreign labor on labor productivity and wages in Malaysian Manufacturig, (2000-2006),"Int. Bank Reconstr. Dev., vol. 93255, pp. 136-158, 2014. 